\section{Chemical characterization of PMIO in two small towns located in South Poland}

\author{
Anna Turek-Fijak (ㅁ, \\ Joanna Brania, \\ Katarzyna Styszko ${ }^{\mathbb{D} \text {, }}$ \\ Damian Zieba, \\ Zdzisław Stęgowski $\mathbb{1}^{\circ}$, \\ Lucyna Samek (1)
}

\begin{abstract}
The purpose of this study is to analyse the elements and PM10 concentrations in air samples gathered in the winter of 2017/2018 in two small towns, namely Skala and Wadowice. The chemical elements were identified for each sample using the energy dispersive X-ray method. The spectrometer was equipped, among others, with an Mo-X-ray tube which was the source of the photons and the $\mathrm{Si}(\mathrm{Li})$ detector. The following chemical elements: $\mathrm{Cl}, \mathrm{K}, \mathrm{Fe}, \mathrm{Ca}, \mathrm{Zn}, \mathrm{Pb}, \mathrm{Br}, \mathrm{Ti}, \mathrm{Cu}, \mathrm{Mn}, \mathrm{V}, \mathrm{Co}, \mathrm{Rb}, \mathrm{Ni}, \mathrm{Sr}$, and $\mathrm{Cr}$ were identified in the samples. In addition, As and Se were identified in Wadowice. First, the results were compared with each other and then with the results for the nearest city. It was observed that the PM10 concentrations were significantly higher than the UE limit value for PM10, which equals $50 \mu \mathrm{g} \cdot \mathrm{m}^{-3}$ per $24 \mathrm{~h}$. Moreover, the high concentrations of, among others, $\mathrm{K}, \mathrm{Pb}, \mathrm{Cl}$ or $\mathrm{Zn}$, are likely to be linked with fossil fuels combustion and biomass burning. The levels of element concentrations in Wadowice and Skala resemble the levels observed several years earlier in Krakow.
\end{abstract}

Keywords: Air pollution • EDXFR fluorescence • PM10

A. Turek-Fijak, J. Brania, D. Zięba, Z. Stęgowski, L. Samek ${ }^{\infty}$

Faculty of Physics and Applied Computer Science AGH University of Science and Technology

Mickiewicza 30 Ave., 30-059 Krakow, Poland

E-mail: lucyna.samek@fis.agh.edu.pl

K. Styszko

Faculty of Energy and Fuels

AGH University of Science and Technology

Mickiewicza 30 Ave., 30-059 Krakow, Poland

Received: 12 March 2020

Accepted: 20 May 2020

\section{Introduction}

Air pollution is one of the scourges of contemporary cities, and numerous researches have demonstrated that poor air quality has a significant impact on human health. The World Health Organization (WHO) has estimated that the rates of human mortality and morbidity caused by exposure to air pollution are on the rise $[1,2]$. This danger is linked, among other reasons, to the presence of airborne particulate matter (APM), which can be defined as a mixture of liquids and solid particulates. APM has both natural and anthropogenic sources. In this article, PM10 will be considered mainly to be the pollution caused by human activity like transport, households, and industry $[3,4]$.

In Poland, the problem of air pollution is severe. Numerous studies carried out in urban areas indicate that the air quality in Poland is one of the worst in the European Union (EU) [5]. The EU limit value for PM10 is $50 \mathrm{mg} \cdot \mathrm{m}^{-3}$ per $24 \mathrm{~h} \mathrm{[6],} \mathrm{but} \mathrm{this} \mathrm{limit}$ is often exceeded, primarily during the cold season. This is mainly caused by nonindustrial combustion processes like the burning of fossil fuels and biomass, especially during the winter [7, 8]. Moreover, adverse and windless weather has an additional impact on poor air quality. The problem of air pollution is also present in small towns, but unfortunately, the exact data concerning the air situation there is limited. However, research on air pollution

0029-5922 @ 2021 The Author(s). Published by the Institute of Nuclear Chemistry and Technology.

This is an open access article under the CC BY-NC-ND 4.0 licence (http://creativecommons.org/licences/by-nc-nd/4.0/). 
in small towns has been conducted and results have proven that the problem of air quality is present [9]. Further, air pollution in Polish cities in the south of the country, regardless of their size, is a serious issue [9]. More research on air pollution in small towns is needed, especially, not only on the concentration of PM, but also on its composition. PM consists mainly of carbon, elements, cations, anions, and organic compounds. The understanding of the chemical content of PM provides us with information about its health implications and sources [1].

This study aims to investigate and compare the elements and PM10 concentrations for two small cities in winter. Due to the analysis of PM content and the particles' size, we can identify sources of pollution and estimate the risk to people and the environment. The following element concentrations: $\mathrm{Cl}, \mathrm{K}, \mathrm{Fe}, \mathrm{Ca}$, $\mathrm{Zn}, \mathrm{Pb}, \mathrm{Br}, \mathrm{Ti}, \mathrm{Cu}, \mathrm{Mn}, \mathrm{V}, \mathrm{Co}, \mathrm{Rb}, \mathrm{Ni}, \mathrm{As}$, Se, Sr, and $\mathrm{Cr}$ were determined for each sample using the X-ray fluorescence method. This paper presents, in the tables and graphs, low limit detection, and elemental and PM10 concentrations, including uncertainties. Element concentrations in two small towns were associated with potential sources of pollution and compared with the results relating to element concentration in the nearest large city - Krakow.

\section{Experimental}

\section{Sampling areas}

The sampling campaigns were conducted in two towns: Skala and Wadowice.

Skala is a small town located $50^{\circ} 23^{\prime} \mathrm{N}$ and $19^{\circ} 85^{\prime} \mathrm{E}$, between the Ojcow National Park in the southwest and the Dlubnia Landscape Park in the southeast. It covers an area of $2.97 \mathrm{~km}^{2}$ and has a population of 3801 people. Skala is located on the slightly undulating Jurassic plateau. In its upper layer, Jurassic limestone and chalk marl covered with clay can be found. Moreover, the city is directly adjacent to the Ojcow National Park, where chalk deposits are located. Skala is a densely built-up commercial and residential area, located at a junction of major roads. Heating is provided mainly by domestic furnaces, tiled stoves, and electrical devices.

Wadowice is a town situated in the valley between the hills of the Pogorze and the Beskid Maly ranges. It covers an area of $10.6 \mathrm{~km}^{2}$ with a population of over $18600\left(49^{\circ} 53^{\prime} \mathrm{N}\right.$ and $\left.19^{\circ} 30^{\prime} \mathrm{E}\right)$. The area is diverse in terms of altitude, because the difference between the highest and the lowest point is about $50 \mathrm{~m}$. Wadowice is a strategic spot in the region, due to the presence of local initiatives: administration, culture, and education centers. The town is also located at a junction of several major roads. Heating is provided by furnaces and power plants.

In accordance with the information presented above, the potential sources of air pollution can be as follows:

- burning of fossil fuels by transport and households (low-emission);

- industrial plants and factories;

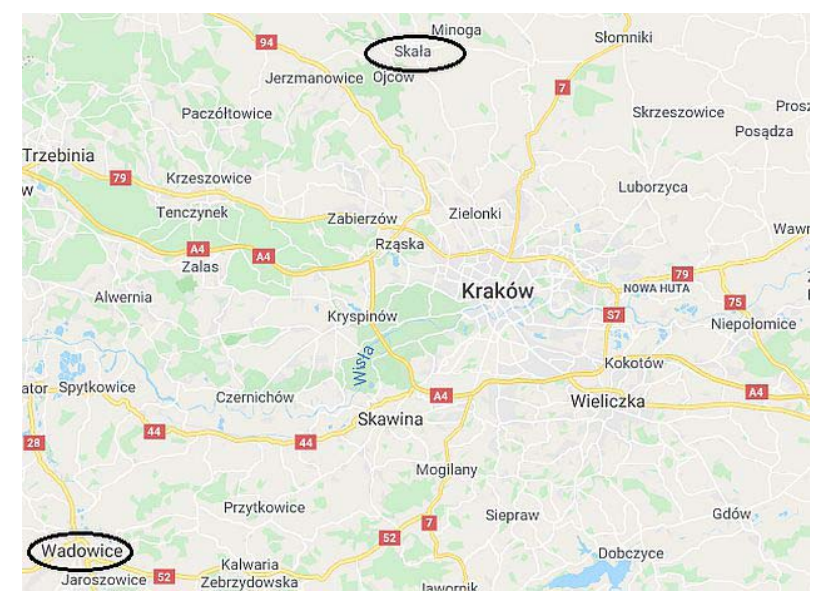

Fig. 1. Map with sampling sites.

- the re-suspension of road dust;

- neighbouring towns or villages;

- other sources.

\section{Sampling site}

The samples were collected between 22 December 2016 and 23 January 2017 in Skala and between 24 January and 20 February 2017 in Wadowice. All samples were collected in the town centers. The sites and the location of the study areas are shown in Fig. 1.

In order to collect the PM10 samples, quartz fiber filters (Whatman, $47 \mathrm{~mm}$ ) were used. The samples were taken using a low-volume sampler, PNS-15. The sampling time was $24 \mathrm{~h}$ for all samples. Before and after the sampling, the filters were conditioned, weighed (microbalance, A\&D HM-202-EC), and stored in specific circumstances (preserving the right temperature and humidity conditions respectively at $20 \pm 1^{\circ} \mathrm{C}$ and $50 \pm 5 \%$ ). The mass was used to calculate the concentration of PM10, pre and postsampling. Filters were stored in a freezer at $-20^{\circ} \mathrm{C}$ until analysis.

\section{Elemental analysis}

The samples were analysed using the energy dispersive X-ray fluorescence (EDXRF) spectrometer available in the laboratory at the Faculty of Physics and Applied Computer Science at AGH University of Science and Technology in Krakow. EDXRF is a nondestructive analytical technique used for measuring element concentrations in the samples.

A multifunctional EDXRF spectrometer was used in this study. This instrument consisted of an Mo-X-ray tube which was the source of photons: the $\mathrm{Si}(\mathrm{Li})$ detector with a $170 \mathrm{eV}$ resolution at $5.9 \mathrm{keV}$, a specimen chamber, and the necessary electronics with a PC. Due to the fact that the X-ray tube had a molybdenum anode, a Mo secondary target was used to gain monochromatic X-ray beams. The excitation energy of Mo is $17.4 \mathrm{keV}$, which means that the elements must have lower excitation energy. The specifications of the tube were as follows: voltage of $55 \mathrm{kV}$ and current of $30 \mathrm{~mA}$. The measurement time for one sample was $10000 \mathrm{~s}$. 
The qualitative and quantitative analysis was conducted using AXIL software. This software was used to analyse the X-ray spectrum and gain necessary information to calculate the element concentrations, uncertainty, and the limit of detection.

The calibration of the spectrometer was performed prior to the time of taking the measurements of the PM10 samples. Calibration was conducted using Micromatter USA thin-film standards. By using AXIL software, the spectra were fitted to a Gaussian curve to obtain the area under peak. Subsequently, sensitivity was established. On the basis of the area under peak and sensitivity, the concentrations were determined.

The results of calibration were satisfactory; the results were verified by analysis of the National Institute of Standards and Technology (NIST) Standard Reference Material (SRM). The measured results of the SRM 2783 were compared with the certified values (Table 1 ), which were equal to the certified values within the measured uncertainties. Only the measured value for $\mathrm{Zn}$ was equal to the certified values within extended uncertainties.

Spectra for samples were fitted to a Gaussian curve to obtain the area under peak. The quantitative analysis was conducted using parameters such as area under peak and sensitivity. Figures 2 and 3 indicate the EDXRF spectra of PM10 samples collected in Skala and Wadowice, respectively.

\section{Results and discussion}

The results of the element concentrations are shown in Table 2. Figures 4 and 5 show the values of PM concentrations and the red line shows the limit value for PM10. Uncertainty for PM10 concentrations is approximately $10 \%$.

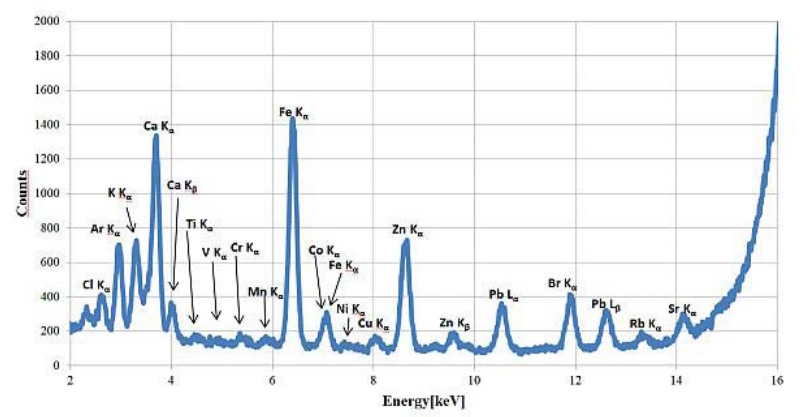

Fig. 2. EDXRF spectra of sample collected in Skala.

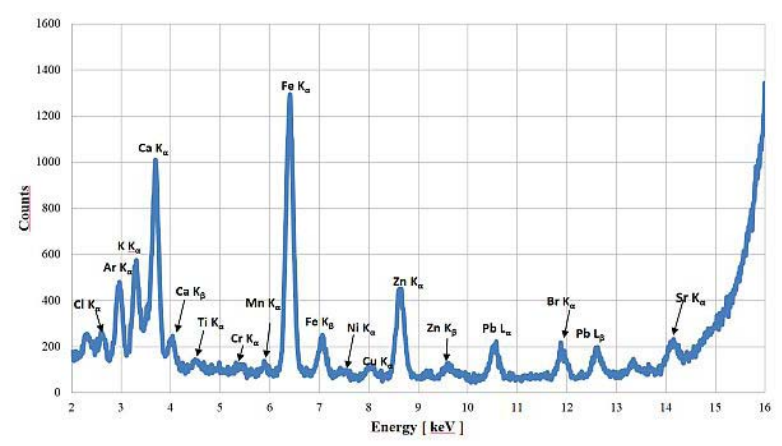

Fig. 3. EDXRF spectra of sample collected in Wadowice.
Table 1. The measured and certified values - SRM 2783

\begin{tabular}{lcc}
\hline Element & $\begin{array}{c}\text { Measured values } \\
(\mathrm{ng})\end{array}$ & $\begin{array}{c}\text { Certified values } \\
(\mathrm{ng})\end{array}$ \\
\hline $\mathrm{K}$ & $6120 \pm 4550$ & $5280 \pm 250$ \\
$\mathrm{Ca}$ & $11240 \pm 3540$ & $13200 \pm 1700$ \\
$\mathrm{Ti}$ & $1400 \pm 170$ & $1490 \pm 240$ \\
$\mathrm{Cr}$ & $150 \pm 85$ & $135 \pm 25$ \\
$\mathrm{Mn}$ & $284 \pm 50$ & $320 \pm 12$ \\
$\mathrm{Fe}$ & $24800 \pm 1910$ & $26500 \pm 1600$ \\
$\mathrm{Cu}$ & $480 \pm 70$ & $404 \pm 42$ \\
$\mathrm{Zn}$ & $2350 \pm 400$ & $1790 \pm 130$ \\
$\mathrm{~Pb}$ & $310 \pm 64$ & $317 \pm 54$ \\
\hline
\end{tabular}

According to laws enacted by the WHO and the EU, the limit value for PM10 is $50 \mu \mathrm{g} \cdot \mathrm{m}^{-3}$ per $24 \mathrm{~h}$. In Skala, the EU limit was exceeded for 18 days out of 30 during which the samples were collected, whereas in Wadowice the EU limit was exceeded on all the days with the exception of one day. Further, the highest concentration of PM10 was $406 \mu \mathrm{g} \cdot \mathrm{m}^{-3}$ for Wadowice and $301 \mu \mathrm{g} \cdot \mathrm{m}^{-3}$ for Skala. The concentration of PM10 of more than $150 \mu \mathrm{g} \cdot \mathrm{m}^{-3}$ (three times above the limit) occurred 15 times in Wadowice and five times in Skala. The concentration which did not exceed the limit occurred only once in Wadowice and 11 times in Skala.

The mean values of element concentration for $\mathrm{Cl}$, $\mathrm{Ca}, \mathrm{K}, \mathrm{Ti}, \mathrm{Mn}, \mathrm{Fe}, \mathrm{Co}, \mathrm{Cu}, \mathrm{Zn}, \mathrm{Br}, \mathrm{Rb}$ in Wadowice is higher than the values in Skala; some of the elements such as $\mathrm{Sr}$ and $\mathrm{Cr}$ have higher mean values in Skala, but $\mathrm{Ni}, \mathrm{V}$, and $\mathrm{Pb}$ have a similar concentration in both of these towns.

High concentrations of chemical elements such as $\mathrm{Cl}, \mathrm{K}, \mathrm{Pb}, \mathrm{Ca}, \mathrm{Ni}, \mathrm{V}$, and As were observed; these elements are connected with fossil fuels combustion [10], whereas K is typical for wood burning or biomass burning [11].



Fig. 4. PM10 concentration for Skala.

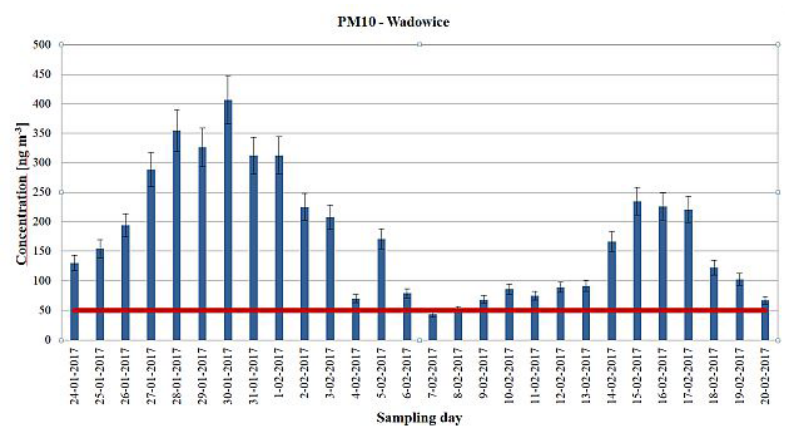

Fig. 5. PM10 concentration for Wadowice. 
Table 2. Average PM10 $\left(\mu \mathrm{g} \cdot \mathrm{m}^{-3}\right)$ and elemental concentrations in Wadowice and Skala $\left(\mathrm{ng} \cdot \mathrm{m}^{-3}\right)$ with low limit of detection (ng. $\mathrm{m}^{-3}$ )

\begin{tabular}{|c|c|c|c|c|c|c|c|}
\hline \multirow{3}{*}{$\mathrm{PM}_{10}$} & \multicolumn{3}{|c|}{ Wadowice } & \multicolumn{3}{|c|}{ Skala } & \multirow{4}{*}{ LLD } \\
\hline & Min & Max & Mean & Min & Max & Mean & \\
\hline & 43 & 407 & 174 & 23 & 301 & 84 & \\
\hline Element & Min & $\operatorname{Max}$ & Mean \pm SD & Min & $\operatorname{Max}$ & Mean \pm SD & \\
\hline $\mathrm{Cl}$ & 407 & 23849 & $9228 \pm 6200$ & 362 & 17733 & $4268 \pm 2740$ & 144 \\
\hline $\mathrm{K}$ & 467 & 2544 & $1400 \pm 540$ & 223 & 1584 & $718 \pm 270$ & 33 \\
\hline $\mathrm{Ca}$ & 190 & 2697 & $590 \pm 290$ & 191 & 754 & $296 \pm 83$ & 23 \\
\hline $\mathrm{Ti}$ & 25 & 139 & $56 \pm 18$ & 17.26 & 64.39 & $29 \pm 7.1$ & 13 \\
\hline V & 10 & 20 & $15 \pm 2.5$ & 11.43 & 44.86 & $17.5 \pm 3.7$ & 9.6 \\
\hline $\mathrm{Cr}$ & 1.02 & 10 & $4 \pm 1.6$ & 4.06 & 25.32 & $9.4 \pm 3.1$ & 1.4 \\
\hline $\mathrm{Mn}$ & 8.62 & 81 & $27 \pm 14$ & 6.09 & 34.26 & $12.3 \pm 4.1$ & 5.8 \\
\hline $\mathrm{Fe}$ & 157 & 2098 & $760 \pm 400$ & 67 & 1004 & $308 \pm 150$ & 3.5 \\
\hline Co & 5.84 & 14 & $8.6 \pm 1.7$ & 4.06 & 7.11 & $5.46 \pm 0.71$ & 3.9 \\
\hline $\mathrm{Ni}$ & 2.29 & 11 & $4.2 \pm 1.8$ & 1.52 & 5.08 & $3.09 \pm 0.79$ & 2.0 \\
\hline $\mathrm{Cu}$ & 5.08 & 62 & $27 \pm 16$ & 2.29 & 17.75 & $8.3 \pm 4$ & 2.1 \\
\hline $\mathrm{Zn}$ & 93 & 749 & $360 \pm 180$ & 57 & 723 & $207 \pm 110$ & 3.3 \\
\hline As & 2.54 & 20 & $11 \pm 4.7$ & - & - & - & \\
\hline $\mathrm{Se}$ & 2.54 & 6 & $4.4 \pm 1.1$ & - & - & - & \\
\hline $\mathrm{Br}$ & 10 & 246 & $95 \pm 63$ & 12.2 & 193.5 & $53 \pm 30$ & 2.1 \\
\hline $\mathrm{Rb}$ & 2.79 & 14 & $7 \pm 2.3$ & 1.52 & 6.59 & $3.3 \pm 1.3$ & 1.7 \\
\hline $\mathrm{Sr}$ & 0.51 & 11 & $4.2 \pm 2$ & 4.57 & 30.39 & $8.3 \pm 2.9$ & 0.4 \\
\hline $\mathrm{Pb}$ & 28 & 286 & $120 \pm 64$ & 34.3 & 357.4 & $98 \pm 50$ & 1.9 \\
\hline
\end{tabular}

SD: standard deviation - the variability of concentrations during the measuring period.

$\mathrm{Zn}$ and $\mathrm{Pb}$ can be associated with the presence of metal works, factories, or smelters located in Wadowice and in the neighbouring towns (e.g., Andrychow) [10]. This also confirms the presence of $\mathrm{Mn}, \mathrm{As}, \mathrm{Se}, \mathrm{Cr}, \mathrm{Ni}$, and $\mathrm{Co}[3,12]$. Further, industrial factors significantly affect air quality, particularly in Wadowice, which is a larger industrial area as compared to Skala. On the other hand, in Skala, the main source of pollution is the combustion of fossil fuels and the transport of aerosols from other towns [13]. The levels of element concentration are higher in Wadowice than in Skala, since the former is a larger town with more sources of pollution.

Furthermore, both in Wadowice and Skala, there is significant car traffic which explains the presence of elements originating from traffic emission: Fe, $\mathrm{Cu}$, and $\mathrm{Rb}$ from brake and engine wear, and $\mathrm{Zn}$ from tires $[14,15]$. Exhaust emissions from motor

Table 3. Comparison of PM10 $\left(\mu \mathrm{g} \cdot \mathrm{m}^{-3}\right)$ and the chemical element concentrations for Wadowice, Skala, and big cities $\left(\mathrm{ng} \cdot \mathrm{m}^{-3}\right)$

\begin{tabular}{|c|c|c|c|c|c|c|c|c|}
\hline Element & Wadowice & Skala & $\begin{array}{l}\text { Krakow } \\
2010 \text { [9] }\end{array}$ & $\begin{array}{c}\text { Krakow } \\
2011[16]\end{array}$ & $\begin{array}{c}\text { Krakow } \\
2012[16]\end{array}$ & $\begin{array}{c}\text { Krakow } \\
2010 \text { [17] }\end{array}$ & $\begin{array}{c}\text { Krakow } \\
2010 \text { [17] }\end{array}$ & $\begin{array}{l}\text { London } \\
2012 \text { [18] }\end{array}$ \\
\hline PM10 & 174 & 84 & - & 93 & 40 & 124 & 92 & - \\
\hline $\mathrm{Cl}$ & 9228 & 4268 & - & - & 1040 & - & - & 790 \\
\hline K & 1400 & 718 & 1042 & 386 & 193 & 737 & 339 & 36.2 \\
\hline $\mathrm{Ca}$ & 590 & 296 & 1216 & 452 & 918 & 858 & 342 & 202 \\
\hline $\mathrm{Ti}$ & 56 & 29 & 52 & 66 & 17 & 66 & 63 & 7.5 \\
\hline V & 15 & 17.5 & - & - & - & - & - & 2.2 \\
\hline $\mathrm{Cr}$ & 4 & 9.4 & 66 & - & - & 47 & 17 & 6.3 \\
\hline $\mathrm{Mn}$ & 27 & 12.3 & 164 & 52 & 16 & 118 & 39 & 9.4 \\
\hline $\mathrm{Fe}$ & 760 & 308 & 4350 & 1300 & 507 & 2960 & 743 & 693 \\
\hline Co & 8.6 & 5.46 & - & - & - & - & - & - \\
\hline $\mathrm{Ni}$ & 4.2 & 3.09 & - & $<$ LLD & $<$ LLD & - & - & 2.1 \\
\hline $\mathrm{Cu}$ & 27 & 8.3 & 24.6 & 23 & 8.7 & 31 & 23 & 26 \\
\hline $\mathrm{Zn}$ & 360 & 207 & 442 & 176 & 141 & 422 & 223 & 10.9 \\
\hline As & 11 & - & 21 & 8 & $<\mathrm{LLD}$ & - & - & - \\
\hline $\mathrm{Se}$ & 4.4 & - & - & - & - & - & - & - \\
\hline $\mathrm{Br}$ & 95 & 53 & 61 & 33 & 49 & 51 & 37 & 2.3 \\
\hline $\mathrm{Rb}$ & 7 & 3.3 & - & $<$ LLD & $<$ LLD & - & - & - \\
\hline $\mathrm{Sr}$ & 4.2 & 8.3 & - & 4.5 & 43.3 & - & - & - \\
\hline $\mathrm{Pb}$ & 120 & 98 & 121 & 52 & 41 & 108 & 68 & 1.6 \\
\hline
\end{tabular}

<LLD: the value is below the detection limit. 
vehicles are connected with the occurrence of, in particular, $\mathrm{Br}, \mathrm{V}, \mathrm{Zn}$, and $\mathrm{Cu}[15]$. In addition, $\mathrm{Ti}$ and $\mathrm{Sr}$ may come from re-suspended road dust [3].

The reason for such high concentrations of PM10 and chemical elements, both in Wadowice and Skala, can be the unfavourable landform and windless weather, but also anthropogenic sources (e.g., combustion of fossil fuels in households, transport and industrial emission).

The values of element concentration in Wadowice and Skala are as follows:

- Wadowice: $\mathrm{Cl}>\mathrm{K}>\mathrm{Fe}>\mathrm{Ca}>\mathrm{Zn}>\mathrm{Pb}>\mathrm{Br}>\mathrm{Ti}>\mathrm{Cu}$

$>\mathrm{Mn}>\mathrm{V}>\mathrm{As}>\mathrm{Co}>\mathrm{Rb}>\mathrm{Se}>\mathrm{Ni}>\mathrm{Sr}>\mathrm{Cr}$;

- Skała: $\mathrm{K}>\mathrm{Fe}>\mathrm{Ca}>\mathrm{Zn}>\mathrm{Pb}>\mathrm{Br}>\mathrm{Ti}>\mathrm{V}>\mathrm{Mn}$

$>\mathrm{Cr}>\mathrm{Cu}>\mathrm{Sr}>\mathrm{Co}>\mathrm{Rb}>\mathrm{Ni}$.

Comparison of the results of chemical element concentration study in Wadowice and Skala with the results obtained in Krakow in 2010 and 2011 leads to the following conclusions: the concentration for $\mathrm{K}$ is the highest in Wadowice, but it is similar in Krakow (2010) [9] (see Table 3). Further, the value of $\mathrm{K}$ is similar in Skala and in Krakow (in the Nowa Huta borough) [16]; $\mathrm{Ca}, \mathrm{Cr}$, and Mn levels were lower in Wadowice and in Skala than in Krakow in 2010 [16]; Ti levels were similar in Wadowice and in Krakow in 2010; Fe was similar in Wadowice and Krowodrza (Krakow) [16]; Cu level is similar in Wadowice and in Krakow (Nowa Huta borough) and in Krakow in 2011 [9, 12]; Zn and As were similar in Wadowice and in Krakow in 2010 [9]; Br concentration was similar in Skala and in Krakow in 2012, and in Nowa Huta and Krakow in 2010 [9, 16, 17]; Sr concentration was similar in Wadowice and in Krakow in 2011 [17]; $\mathrm{Pb}$ concentration was similar in Wadowice and in Skala and they were both similar to Krakow (Nowa Huta) and to Krakow in 2010 [9, 16].

For illustrative purposes, the results for cities larger than Wadowice and Skala are presented in Table 3 . The values for most concentrations are different for Wadowice, Skala, and roads in London. The differences for $\mathrm{Cl}, \mathrm{K}, \mathrm{Br}, \mathrm{Zn}$, and $\mathrm{Pb}$ are particularly interesting between Wadowice, Skala, and London. However, it can be also observed that there is a similarity for $\mathrm{Cr}, \mathrm{Fe}$, and $\mathrm{Ni}$.

\section{Conclusions}

The aim of this study was to assess and compare the air quality in two small towns in the region of Lesser Poland (Wadowice and Skala).

The EU limit levels of PM10 concentrations were exceeded on most of the sampling days. The main result of this study was based on the concentration of chemical elements. The mean values of chemical concentrations, for example, $\mathrm{Cl}, \mathrm{K}, \mathrm{Ca}, \mathrm{Fe}$, and $\mathrm{Br}$ were higher for Wadowice than Skala. On the other hand, $\mathrm{Cr}$ and $\mathrm{Sr}$ were higher in Skala and a few elements whose concentrations were similar. The combustion of fossil fuels and biomass can be the source of element concentration of $\mathrm{Cl}, \mathrm{K}, \mathrm{Pb}, \mathrm{Ca}$, and $\mathrm{V}$. It can be observed that the presence of metal works and factories could have a significant impact on poor air condition because of the toxic metals that were released into the environment. Moreover, the pollution caused by road dust and neighbouring towns or villages may have contributed to the deterioration in air quality.

The element concentrations for Wadowice and Skala were compared with the results obtained in Krakow in 2010 and 2011. This analysis has proved that many similarities exist in the results of element concentrations. This similarity in the composition of air pollutants in towns of different sizes is encountered throughout Europe [7]. The results clearly demonstrate that the PM10 concentration is high and, perhaps more surprisingly, that it is not altogether different from the level of pollution which occurred in large cities a few years ago.

Acknowledgments. This work was partially supported by the AGH University of Science and Technology statutory tasks subsidy of the Ministry of Science and Higher Education (16.16.210.476). The authors thank the Krakow Smog Alert for collecting samples and the $\mathrm{PhD}$ students of the Faculty of Energy and Fuels for help in the collection of samples.

\section{ORCID}

L. Samek (1) http://orcid.org/0000-0001-8636-2771

Z. Stegowski (1) http://orcid.org/0000-0001-7480-5811

K. Styszko (1) http://orcid.org/0000-0003-0092-3772

A. Turek-Fijak (I) http://orcid.org/0000-0003-1025-6141

\section{References}

1. Tarín-Carrasco, P., Morales-Suárez-Varela, M., Im, U., Brandt, J., Palacios-Peña, L., \& Jiménez-Guerrero, P. (2019). Isolating the climate change impacts on air-pollution-related-pathologies over central and southern Europe - A modelling approach on cases and costs. Atmos. Chem. Phys., 19, 9385-9398. https:// doi.org/10.5194/acp-19-9385-2019.

2. World Health Organization. (2005). WHO Air quality guidelines for particulate matter, ozone, nitrogen dioxide and sulfur dioxide: Global update 2005, 1-21. Available from https://doi.org/10.1016/00046981(88)90109-6.

3. Querol, X., Viana, M., Alastuey, A., Amato, F., Moreno, T., Castillo, S., Pey, J., de la Rosa, J., de la Campa, A. S., Artinano, B., Salvador, P., Dos Santos, S. G., Fernandez-Patier, R., Moreno-Grau, S., Nergal, L., Minguillon, M. C., Monfort, E., Gil, J. I., Inza, A., Ortega, L. A., Santamaria, J. M., \& Zabalza, J. (2007). Source origin of trace elements in PM from regional background, urban and industrial sites of Spain. Atmos. Environ., 41(34), 7219-7231. https:// doi.org/10.1016/j.atmosenv.2007.05.022.

4. Visser, S., Slowik, J. G., Furger, M., Zotter, P., Bukowiecki, N., Canonaco, F., Flechsig, U., Appel, K., Green, D. C., Tremper, A. H., Young, D. E., Williams, P. I., Allan, J. D., Coe, H., Williams, L. R., Mohr, C., Xu, L., Ng, N. L., Nemitz, E., Barlow, J. F., Halios, C. 
H., Fleming, Z. L., Baltensperger, U., \& Prévôt, A. S. H. (2015). Advanced source apportionment of sizeresolved trace elements at multiple sites in London during winter. Atmos. Chem. Phys., 15(19), 11291-11309. https://doi.org/10.5194/acp-15-11291-20115.

5. Zieliński, E., Wielgus, A., Dreliszak, J., \& Zukow, W. (2018). Air pollution - selected health effects in Poland. Journal of Education, Health and Sport, 8(12), 641-648. http://dx.doi.org/10.5281/zenodo.2527086.

6. European Council. (2008). Directive 2008/50/EC of the European Parliament and of the Council of 21 May 2008 on ambient air quality and cleaner air for Europe. (2008/50/EC).

7. Lin, C., Ceburnis, D., Huang, R. -J., Xu, W., Spohn, T., Martin, D., Buckley, P., Wenger, J., Hellebust, S., Rinaldi, M., Facchini, M. C., O'Dowd, C., \& Ovadnevaite, J. (2019). Wintertime aerosol dominated by solid fuel burning emissions across Ireland: insight into the spatial and chemical variation of submicron aerosol. Atmos. Chem. Phys., 5, 14091-14106. https://doi. org/10.5194/acp-19-14099-2019.

8. Vasev, N. (2017). Governing energy while neglecting health - The case of Poland. Health Policy, 121(11), 1147-1153. https://doi.org/10.1016/j.healthpol.2017.09.008.

9. Samek, L., Zwoździak, A., \& Sówka, I. (2013). Chemical characterization and source identification of particulate matter PM 10 in a rural and urban site in Poland. Environ. Prot. Eng., 39(4), 91-103. https:// doi.org/10.5277/epe130408.

10. Crilley, L. R., Lucarelli, F., Bloss, W. J., Harrison, R. M., Beddows, D. C., Calzolai, G., Nava, S., Valli, G., Bernardoni, V., \& Vecchi, R. (2017). Source apportionment of fine and coarse particles at a roadside and urban background site in London during the 2012 summer ClearfLo campaign. Environ. Pollut., 220, 766-778. https://doi.org/10.1016/j.envpol.2016.06.002.

11. Harrison, R. M., Beddows, D. C. S., Hu, L., \& Yin, J. (2012). Comparison of methods for evaluation of wood smoke and estimation of UK ambient concen- trations. Atmos. Chem. Phys., 12(17), 8271-8283. https://doi.org/10.5194/acp-12-8271-2012.

12. Reizer, M., \& Juda-Rezler, K. (2016). Explaining the high PM10 concentrations observed in Polish urban areas. Air Quality, Atmosphere and Health, 9(5), 517-531. https://doi.org/10.1007/s11869-015-0358-z.

13. ALBEKO. (2012). Program ochrony środowiska dla gminy Skała na lata 2012-2015 z perspektywa na lata 2016-2019. Opole: ALBEKO.

14. Belis, C. A., Pikridas, M., Lucarelli, F., Petralia, E., Cavalli, F., Calzolai, G., Berico, M., \& Sciare, J. (2019). Source apportionment of fine PM by combining high time resolution organic and inorganic chemical composition datasets. Atmos. Environ. X, 3, 100046. https://doi.org/10.1016/j.aeaoa.2019.100046.

15. Pant, P., \& Harrison, R. M. (2013). Estimation of the contribution of road traffic emissions to particulate matter concentrations from field measurements: A review. Atmos. Environ., 77, 78-97. https://doi. org/10.1016/j.atmosenv.2013.04.028.

16. Samek, L., Stegowski, Z., \& Furman, L. (2016). Preliminary PM2.5 and PM10 fractions source apportionment complemented by statistical accuracy determination. Nukleonika, 61(1), 75-83. https:// doi.org/10.1515/nuka-2016-0014.

17. Samek, L. (2012). Source apportionment of the PM10 fraction of particulate matter collected in Kraków, Poland. Nukleonika, 57(4), 601-606.

18. Visser, S., Slowik, J. G., Furger, M., Zotter, P., Bukowiecki, N., Dressler, R., Flechsig, U., Appel, K., Green, D. C., Tremper, A. H., Young, D. E., Williams, P. I., Allan, J. D., Herndon, S. C., Williams, L. R., Mohr, C., Xu, L., Ng, N. L., Detournay, A., Barlow, J. F., Halios, C. H., Fleming, Z. L., Baltensperger, U., \& Prévôt, A. S. H. (2015). Kerb and urban increment of highly time-resolved trace elements in PM10, PM2.5 and PM1.0 winter aerosol in London during ClearfLo 2012. Atmos. Chem. Phys., 15(5), 2367-2386. https:// doi.org/10.5194/acp-15-2367-2015. 